\title{
POLA BAKTERI PADA URIN PASIEN YANG MENGGUNAKAN KATETER URETRA DI INSTALASI RAWAT INAP RSUP PROF. DR. R. D. KANDOU MANADO
}

\author{
${ }^{1}$ Jemmy C. Sie \\ ${ }^{2}$ Olivia Waworuntu \\ ${ }^{2}$ John Porotuo
}

\author{
${ }^{1}$ Kandidat Skripsi Fakultas Kedokteran Universitas Sam Ratulangi Manado \\ ${ }^{2}$ Bagian Mikrobiologi Fakultas Kedokteran Universitas Sam Ratulangi Manado \\ Email: jemmysie@gmail.com
}

\begin{abstract}
One of the most common nosocomial infection is urinary tract infection (UTI); $80 \%$ of cases are associated with the use of urethral catheters. The most common pathogens are Escherichia coli, Enterococcus, Klebsiella, Pseudomonas, Proteus, and Enterobacter species. Bacteria patterns could change from time to time and from area to area. This study aimed to obtain the bacteria pattern in urine of patients using urethral catheter.This was a descriptive prospective study. There were 20 urine samples from November 2013 until January 2014 in IRINA RSUP Prof Dr RD Kandous Manado. The results showed that age $>60$ years was the most common age group (41.8\%). Males (84.9\%) were predominantly affected in this study. Staphylococcus epidermidis was found in $20 \%$ of samples, followed by several other bacteria. Conclusion: The most affected age group using urethral catheter with bacteriuria was over 60 years, more frequent in males, and the most common pathogen was Staphylococcus epidermidis.
\end{abstract}

Keywords: bacteria, bacteria pattern, urinary tract infection, nosocomial infection, urethral catheter

\begin{abstract}
Abstrak: Salah satu infeksi nosokomial yang sering terjadi adalah infeksi saluran kemih (ISK), 80\% kasus ISK diasosiasikan dengan penggunaan kateter uretra. Patogen yang paling sering ditemukan adalah Escherichia coli, Enterococcus, Klebsiella, Pseudomonas, Proteus, dan Enterobacter. Pola bakteri dapat berbeda dari waktu ke waktu dan dari daerah ke daerah. Penelitian ini bertujuan untuk mengetahui pola bakteri pada urin pasien yang menggunakan kateter.Penelitian ini menggunakan desain penelitian deskriptif prospektif pada 20 sampel urin selama bulan November 2013 hingga Januari 2014 di instalasi rawat inap RSUP Prof. Dr. R. D. Kandou Manado. Hasil penelitian memperlihatkan umur 61-70 tahun merupakan insidensi tertinggi. Jumlah sampel laki-laki dengan bakteriuria lebih banyak dibandingkan perempuan. Simpulan: Kelompok umur tersering yang menggunakan kateter uretra dengan bakteriuria ialah umur di atas 60 tahun, lebih sering pada lakilaki, dan bakteri yang paling banyak ditemukan Staphylococcus epidermidis.
\end{abstract}

Kata kunci: bakteri, pola bakteri, infeksi saluran kemih, infeksi nosokomial, kateter uretra

Infeksi

saluran kemih (ISK) adalah salah satu infeksi nosokomial yang sering terjadi, 80\% kasus ISK diasosiasikan dengan penggunaan kateter uretra. Biaya yang dihabiskan untuk Catheter-Associated
Urinary Tract Infection (CAUTI) di Amerika Serikat diperkirakan mencapai \$1006 per kasusnya. Di tahun 2002 diperkirakan 13.088 kematian dikaitkan dengan ISK. ${ }^{1}$ 
Fakta menunjukkan bahwa 25-50\% infeksi nosokomial ternyata merupakan kombinasi dari flora normal pada pasien dengan alat-alat invasif. Hampir semua ISK nosokomial disebabkan oleh instrumentasi yang terdahulu dan kateter uretra yang menetap, membuat resiko infeksi mencapai 3-10\% per hari. Walaupun ISK mengontribusi 10-15\% perpanjangan waktu rawat inap biaya tambahan di rumah sakit, Infeksi-infeksi ini adalah reservoir penting dan sumber dari penyebaran resistensi antibiotik di rumah sakit. ${ }^{2}$

Faktor resiko utama dari perkembangan CAUTI adalah durasi dari kateterisasi. Membatasi penggunaan kateter dan, ketika pemasangan kateter diindikasikan, minimalisasi durasi kateter in situ adalah strategi primer untuk pencegahan CAUTI. Faktor resiko tambahan termasuk jenis kelamin wanita, usia yang lebih tua, dan tidak mengatur sistem drainase tertutup. ${ }^{3}$ Catheterassociated Urinary Tract Infection umumnya disebabkan oleh patogen yang menyebar pada ruang periuretral dari perineum pasien atau saluran pencernaan atau melalui kontaminasi intraluminal dari kateter uretra biasanya akibat infeksi silang dari petugas kesehatan yang mengirigasi kateter atau mengosongkan kantong drainase. Patogen yang sering ditemukan adalah Escherichia coli, basil gram-negatif nosokomial, Enterococcus, dan Candida. ${ }^{2,5}$

\section{METODE PENELITIAN}

Penelitian ini dilakukan pada bulan November 2013 - Januari 2014. Penelitian ini dilaksanakan dengan pengambilan sampel pada Instalasi Rawat Inap RSUP Prof. Dr. R. D. Kandou Manado, kemudian sampel dibawa dan diperiksa di Laboratorium Mikrobiologi Fakultas Kedokteran Universitas Sam Ratulangi Manado. Penelitian ini bersifat deskriptif dan subjek penelitian adalah pasien dewasa yang menggunakan kateter uretra.

\section{HASIL PENELITIAN}

Pada penelitian yang dilakukan pada bulan November 2013 - Januari 2014 ditemukan 20 sampel urin yang diambil dari kateter uretra di Instalasi Rawat Inap RSUP Prof. Dr. R. D. Kandou. Hasil penelitian menunjukkan bahwa pasien dengan bakteriuria terbanyak adalah jenis kelamin laki-laki. (Tabel 1).

Tabel 1. Distribusi bakteriuria berdasarkan jenis kelamin

\begin{tabular}{ccccc}
\hline & \multicolumn{4}{c}{ Jenis Kelamin } \\
\cline { 2 - 5 } Bakteriuria & \multicolumn{2}{c}{ Laki-laki } & \multicolumn{2}{c}{ Perempuan } \\
\hline Positif & 7 & $50 \%$ & 5 & $83,3 \%$ \\
Negatif & 7 & $50 \%$ & 1 & $16,7 \%$ \\
\hline Total & 14 & $100 \%$ & 6 & $100 \%$ \\
\hline
\end{tabular}

Dari data penelitian diperoleh pasien dengan bakteriuria yang paling banyak adalah pada kelompok umur $>60$ tahun. (Tabel 2). 
Tabel 2. Distribusi bakteriuria berdasarkan kelompok umur

\begin{tabular}{ccccc}
\hline \multirow{2}{*}{ Bakteriuria } & \multicolumn{4}{c}{ Bakteriuria } \\
\cline { 2 - 5 } & \multicolumn{2}{c}{ Positif } & \multicolumn{2}{c}{ Negatif } \\
\hline $\mathbf{2 0}$ & 1 & $8,3 \%$ & 0 & $0 \%$ \\
$\mathbf{2 1 - 3 0}$ & 1 & $8,3 \%$ & 1 & $12,5 \%$ \\
$\mathbf{3 1 - 4 0}$ & 1 & $8,3 \%$ & 0 & $0 \%$ \\
$\mathbf{4 1 - 5 0}$ & 3 & $25 \%$ & 1 & $12,5 \%$ \\
$\mathbf{5 1 - 6 0}$ & 1 & $8,3 \%$ & 3 & $37,5 \%$ \\
$>\mathbf{6 0}$ & 5 & $41,8 \%$ & 3 & $37,5 \%$ \\
\hline Total & 12 & $100 \%$ & 8 & $100 \%$ \\
\hline
\end{tabular}

Setelah dilakukan pemeriksaan di laboratorium mikrobiologi, didapatkan hasil pertumbuhan bakteri pada media terdapat 7 jenis bakteri dan yang paling sering ditemukan adalah Staphylococcus epidermidis (Tabel 3).

Tabel 3. Distribusi bakteri pada urin kateter berdasarkan media pertumbuhan.

\begin{tabular}{cccccc}
\hline \multicolumn{1}{c}{ Media NA } & & \multicolumn{4}{c}{ Media MC } \\
\hline Bakteri & $\mathbf{N}$ & $\mathbf{\%}$ & Bakteri & $\mathbf{N}$ & $\mathbf{\%}$ \\
\hline $\begin{array}{c}\text { Staphylococcus } \\
\text { epidermidis }\end{array}$ & 4 & 20,0 & Enterobacter cloacae & 2 & 10,0 \\
Basil subtilis & 3 & 15,0 & Citrobacter freundii & 1 & 5,0 \\
Streptococcus sp. & 2 & 10,0 & $\begin{array}{c}\text { Seratia liquefaciens } \\
\text { Enterobacter }\end{array}$ & 1 & 5,0 \\
TAP & 11 & 55,0 & $\begin{array}{c}\text { agglomerans } \\
\text { TAP }\end{array}$ & 1 & 5,0 \\
& & & Total & $\mathbf{2 0}$ & $\mathbf{1 0 0 , 0}$ \\
\hline Total & $\mathbf{2 0}$ & $\mathbf{1 0 0 , 0}$ & &
\end{tabular}

\section{BAHASAN}

Berdasarkan penelitian yang dilakukan pada bulan November 2013 - januari 2014 di Instalasi Rawat Inap RSUP Prof Dr. R. D. Kandou Manado didapatkan 20 pasien yang menggunakan kateter uretra yang positif ditemukan bakteri pada urin yaitu terdiri dari kelompok umur $<20$ tahun satu orang $(8,3 \%), 21-30$ tahun satu orang (8,3\%), 31-40 satu orang (8,3\%), 41-50 tiga orang (25\%), 51-60 satu orang (8,3\%), dan >60 lima orang (41,8\%). Penelitian Dimri di India (2013) juga memperlihatkan hasil yang sama yaitu 
pasien dengan kelompok umur $>60$ tahun merupakan kelompok umur terbanyak yang menggunakan kateter dengan hasil kultur positif sebanyak 53 orang $(67,1 \%){ }^{5}$ Usia lanjut merupakan salah satu faktor resiko untuk menderita ISK karena status imunitas yang menurun dan penyakit penyerta (diabetes). ${ }^{1,2,6}$

Dari 20 pasien yang menggunakan kateter uretra di Instalasi Rawat Inap RSUP Prof. Dr. R. D. Kandou Manado dari bulan November 2013 hingga Januari 2014 ditemukan 7 sampel urin dengan hasil kultur positif pada laki-laki dan 5 urin dengan hasil kultur positif pada perempuan. Menurut kepustakan dan penelitian sebelumnya, jenis kelamin perempuan dikatakan lebih beresiko dibandingkan laki-laki karena struktur anatomi uretra perempuan yang lebih pendek (sekitar $4 \mathrm{~cm}$ ) dan juga proksimitasnya terhadap anus. ${ }^{2-4}$ Hasil pada penelitian ini mirip dengan penelitian sebelumnya oleh Dimri (2013) di India dimana laki-laki juga lebih banyak menderita ISK akibat kateter. ${ }^{5}$

Pada pemeriksaan kultur urin di Laboratorium Mikrobiologi Fakultas Kedokteran Universitas Sam Ratulangi terhadap 20 sampel urin didapatkan 7 jenis bakteri. Bakteri yang ditemukan pada penelitian ini adalah Staphylococcus epidermidis sebanyak 4 (20\%), Basil subtilis sebanyak 3 (15\%), Enterobacter cloacae sebanyak 2 (10\%), Enterobacter agglomerans sebanyak 1 (5\%), Citrobacter freundii sebanyak 1 (5\%), Seratia liquefaciens sebanyak 1 (5\%), Streptococcus sp. sebanyak 2 (5\%) dan sisanya $65 \%$ tidak ada pertumbuhan. Bakteri yang paling sering ditemukan pada penelitian ini adalah Staphylococcus epidermidis (20\%), hasil yang sama juga didapatkan oleh Hasibuan (2007) dimana bakteri yang paling banyak ditemukan pada instalasi rawat inap adalah Staphylococcus epidermidis yaitu 4 sampel dari 11 sampel positif ISK $(36,4 \%){ }^{7}$ Penelitian ini berbeda dengan penelitian Maki (2001) di berbagai rumah sakit di
Amerika Serikat, ditemukan patogen yang paling banyak ditemukan adalah Escherichia coli (26\%). Menurut kepustakaan tentang ISK akibat pemasangan kateter, bakteri yang paling sering ditemukan adalah E. coli. ${ }^{2,8-9}$ Staphylococcus epidermidis merupakan flora normal pada kulit dan menjadi penyebab infeksi nosokomial pada pasienpasien rawat inap yang menggunakan kateter urin belakangan ini seperti yang didapatkan oleh Rasheed (2006). ${ }^{10}$

Meskipun telah banyak dilakukan penelitian tentang pola bakteri pada urin pasien yang menggunakan kateter, ternyata terdapat perbedaan distribusi pola bakteri penyebabnya dan berubaha dari waktu ke waktu dan bervariasi dari suatu rumah sakit dan lokasi suatu rumah sakit. ${ }^{5,7}$

\section{SIMPULAN}

Berdasarkan hasil penelitian dapat disimpulkan bahwa hampir semua sampel yang diperoleh dari urin pasien yang menggunakan kateter uretra di Instalasi Rawat Inap RSUP Prof. Dr. R. D. Kandou Manado periode November 2013 - Januari 2014 memperlihatkan pertumbuhan bakteri. Dari pola bakteri yang didapat, Staphylococcus epidermidis merupakan bakteri yang paling sering ditemukan. Kelompok umur yang paling sering terdapat bakteri pada urinnya adalah kelompok umur $>60$ tahun, dan jenis kelamin yang paling banyak terpapar adalah jenis kelamin laki-laki.

\section{SARAN}

Perbedaan tempat dan waktu dapat menyebabkan perbedaan pola bakteri. Disarankan untuk dilakukan penelitian uji kepekaan antimikroba agar dapat ditemukan antimikroba yang paling sensitif untuk pola bakteri di instalasi rawat inap yang telah ditemukan pada penelitian ini. Perlu diadakan pelatihan tentang kateter (pemasangan, pengambilan sampel, dan pelepasan) agar dapat mencegah kontaminasi dari petugas medis. 


\section{DAFTAR PUSTAKA}

1. Conway LJ, Larson L. Guidelines to prevent catheter-associated urinary tract infection: 1980 to 2010. Heart Lung. 2012; 41(3): 271-283.

2. Fauci AS, Braunwald E, Isselbacher KJ, Wilson JD, Martin JB, Kasper DL, et al, editors. Harrison's principles of internal medicine. 17th Ed. New York: McGraw Hill, Health Professions Division; 2008.

3. Lo E, et al. Strategies to Prevent Catheter-Associated Urinary Tract Infections in Acute Care Hospitals. The Society for Healthcare Epidemiology of America. 2008, 29:s41-s50.

4. Maki DG, Tambyah PA. Engineering Out the Risk for Infection with Urinary Catheters. Emerging Infectious Disease. 2001 March-April; 7(2).

5. Dimri S, Sharma H, Datta SK, Gupta D. A Study of Urinary Tract Infections in Patients with Cathteter in Tertiary Care Hospital in Western Uttar Pradesh.
International Journal of Contemporary Surgery. 2013 JulyDecember; 1(2): p. 83-86.

6. Soejono $\mathrm{CH}$. Infeksi Saluran Kemih pada Geriatri. Majalah Kedokteran Indonesia. 2005 Maret; 55(3): p. 165-168.

7. Hasibuan H. Pola Kuman pada Urin Penderita yang Menggunakan Kateter Uretra di Ruang Perawatan Intensif dan Bangsal Bedah. 2007.

8. Kayser FH, Bienz KA, Eckert J, Zinkernagel RM. Colour Atlas of Medical Microbiology. 1st ed. New York: Thieme; 2005.

9. Ryan KJ. Urinary Tract Infection. In Ryan KJ, Ray CG, editors. Sherris Medical Microbiology. 4th ed. New York: McGraw-Hill; 2004. p. 867-871.

10. M Rasheed, M Awole. Staphylococcus epidermidis: A Commensal Emerging as a Pathogen with Increasing Clinical Significance Especially in Nosocomial Infections. The Internet Journal of Microbiology. 2006 Volume 3 Number 2. 